\title{
Regional Disparity Analysis: The Case of Romania
}

\author{
Monica Boldea, Mihai Parean and Maria Otil
}

Faculty of Economics and Business Administration, West University, Timisoara, Romania

\begin{abstract}
The present research has several starting points. First, the researchers have considered the strong regional tradition of Romania. Second, the research takes account of the must and need of applying sustainable regional development policies, the European objective being to reduce disparities, which were quite deepened in the last 50 years among the country's regions. An analysis was thus needed to identify the situation of the regions of development in Romania, an analysis that can be considered when establishing the options regarding the attitudes towards the future of a local or regional administrative unit.
\end{abstract}

In this regard, based on the points of view of Polese (1994) and Duvernay (1981), the present research puts forward a model for assessing regional disparities, in the context of the current economic crisis, pursuing an analysis of the regions of development at the beginning of the crisis, which overlapped with the end of a period of sustained economic growth. The model involves mainly labor productivity, simultaneous changes registered by productivity and employment, subsequently leading to the identification - at micro-regional level - of types of conditions favorable or less favorable to development.

Applying this model to the regions of development in Romania, the study aims to identify the current status of these regions of development, calculating the average rates of the three indicators included in the model (GDP, productivity and employment) - for each region separately. The study highlights the existence of a center-periphery structure type, indicating extreme difficulty in identifying a viable pattern regarding diffusion of beneficial effects for the community - from areas benefiting from concentration of industrial and tertiary activities towards other areas.

Key words: regional disparities, regions of development, administrative-territorial units, regional development policies.

\section{Introduction}

The regions have evolved and developed in different way and at a different pace, so a very heterogeneous landscape is to be witnessed in terms of development. The current discrepancies are due to different development rates, to uneven distribution of technical and social infrastructure within countries, along its underdevelopment stage, to demographic imbalances, and to natural factors and different resources to be found from one region to another.
After 1990, the Romanian economy has entered a complex process of restructuring aimed at increasing economic efficiency, and respectively its adaptation to the requirements of the market economy, this process having a territorial economic and social impact from one area to another. Amid political and economic transformations that have developed after the post-revolutionary events, a new concept on regional development policy appeared and was developed, which led to the setting up of the legal and institutional

Copyright (C) 2012 Monica Boldea, Mihai Parean and Maria Otil. This is an open access article distributed under the Creative Commons Attribution License unported 3.0, which permits unrestricted use, distribution, and reproduction in any medium, provided that original work is properly cited. Contact author: Monica Boldea E-mail: monica.boldea@feaa.uvt.ro 
framework, as well as to establishing specific mechanisms. In a relatively short time, the regional development policy in Romania became integrative part of the EU accession process, becoming a distinct negotiation chapter in the EU accession process, respectively Chapter 21 "Regional policy and the coordination of structural instruments". Based on the EU Association Agreement and the National Program for Accession to the EU in the period 1998 to 1999, and with the support of the PHARE program, the legal framework and the institutional structures were set up both at central and at regional levels in Romania, recognizing the need for a modern integrated regional development policy. These structures represent a means of supporting local economic and social potential through cooperation among national, regional and local authorities, and benefitting from financial support from the
Government and the European Commission. Thus, law 151/1998 on regional development in Romania - the basic law on regional development in Romania - is the law that sets the objectives, the institutional framework, the competencies and the instruments needed to promote the regional development policy. This law, which was amended by Emergency Ordinance 268/2000, sets the executive and decision-making bodies at both regional and national levels.

Following these legislative provisions, 8 regions have been established corresponding to NUTS II statistical level, thus not being considered administrative units. The regions of development were formed by the counties' association to a higher level, and they are named after their geographical position in the country (Table no. 1).

Table No.1 - Macro-Regions and Regions of Development in Romania

\begin{tabular}{|c|c|c|c|c|c|c|c|c|}
\hline NUTS I & \multicolumn{2}{|c|}{ Macro-region I } & \multicolumn{2}{|c|}{ Macro-region II } & \multicolumn{2}{|c|}{ Macro-region III } & \multicolumn{2}{|c|}{ Macro-region IV } \\
\hline NUTS II & $\begin{array}{l}\text { North- } \\
\text { West }\end{array}$ & Centre & $\begin{array}{l}\text { North- } \\
\text { East }\end{array}$ & $\begin{array}{l}\text { South- } \\
\text { East }\end{array}$ & $\begin{array}{l}\text { South- } \\
\text { Muntenia }\end{array}$ & $\begin{array}{l}\text { Bucharest- } \\
\text { Ilfov }\end{array}$ & $\begin{array}{l}\text { South- } \\
\text { West }\end{array}$ & West \\
\hline \multirow{7}{*}{ NUTS III } & Bihor & Alba & Bacău & Brăila & Argeș & Bucharest & Dolj & Arad \\
\hline & $\begin{array}{l}\text { Bistriţa - } \\
\text { Năsăud }\end{array}$ & Braşov & Botoşani & Buzău & Călăraşi & \multirow[t]{6}{*}{ Ilfov } & Gorj & $\begin{array}{l}\text { Caraş- } \\
\text { Severin }\end{array}$ \\
\hline & Cluj & Covasna & Iaşi & Constanţa & Dâmbovița & & Mehedinţi & Hunedoara \\
\hline & Maramureş & Harghita & Neamţ & Galaţi & Giurgiu & & Olt & \multirow[t]{4}{*}{ Timiş } \\
\hline & Satu Mare & Mureș & Suceava & Tulcea & Ialomiţa & & \multirow[t]{3}{*}{ Vâlcea } & \\
\hline & Sălaj & Sibiu & Vaslui & Vrancea & Prahova & & & \\
\hline & & & & & Teleorman & & & \\
\hline
\end{tabular}

Source: Author's own processing based on the provisions of law 151/1998

Later on, by grouping the eight regions, four macro-regions of development were set corresponding to NUTS 1 level. Within the Romanian regional structure of NUTS type, only the NUTS III territorial units comprising the 41 counties and Bucharest - dispose of territorial administrative competencies. The macro-regions and the regions of development have neither administrative statute nor their own form of governance or administration.

In order to address these issues and meet the difficulties induced by regional disparities, policies of regional economic development are applied at region level. Regional development policies are integrative part of the national economic strategies on medium term and long term, aiming to improve regional economic conditions on medium and long term, in order to induce the normal operation of market mechanisms and thus leading to the accomplishment of a relative balance between the levels of economic and social development of different regions in a national territory or to providing a specific interregional fairness.

Regional development policies function either by removing the causes that have 
generated the lack of development or the difficult development of a region, or by eliminating the effects that caused the lagging behind or the underdevelopment of regions. Very often the first option would be indicated because, if a negative phenomenon is left to persist, it is likely to cause negative effects on other sectors as well.

The current crisis is the result of three factors: the effects of social and technical division of labor, urban changes and the institutional changes, with influence on the level of territorial differentiation regarding labor productivity and thus on employment.

\section{Model for Regional Disparity Analysis}

Considering the situation induced by the serious economic and financial crisis (officially acknowledged in Romania on October 1, 2008) this research pursues an analysis of the regions of development in Romania at the beginning of this crisis and at the end of a period of sustained economic growth which disposed of a high intake of foreign direct investments. These investments, especially when they were made of large international companies, have been accompanied by a transfer of technology and know-how, leading to a more efficient economic activity. Labor productivity has significantly increased in the Romanian economy and allowed the partial recovery of the gap towards the EU, from $28.2 \%$ of the EU25 average in 2000 to a percentage of $38.8 \%$ in 2006 (Muresan, 2008). According to the official data, the growth continued in the period 2007-2008, and consequently labor productivity in Romania, reported to the EU27 average, increased from $39.2 \%$ in 2006 to $43.7 \%$ in 2007 and to $46.6 \%$ in 2008 .

Economically and statistically, labor productivity is either favored or disfavored by structural process specific to regional policies.

A high level of productivity occurs when general conditions for development are met $^{1}$ :
A stable situation - when productivity growth does not imply any loss at employment level. This is the case of regions with delayed development, which dispose of unused resources, and which through the borrowing of production processes and organization forms from more developed regions and based on their innovative entrepreneurial character - make room for new initiatives.

Reconversion and reallocation of productive resources from sectors lagging behind towards more advanced sectors, with a balance of employment close to zero or slightly negative due to a qualitative difference in the ratio of employment demand / offer.

Technical and organizational restructuring or rearrangement of existing production through the adoption of new procedures or automation of manufacturing and administrative functions.

Abandonment or movement of certain production or some outdated phases of the production process, resulting in an increase in regional unemployment. In this regard, the movement from agriculture towards industry and other activities shaped at that particular time the framework of a rapid increase of the overall productivity, due to higher technical endowment of labor. The structural changes have created a situation where the industry suppresses a number of jobs without having another sector absorb the newly created unemployment. Decreasing the mobility of resources from one sector to another, as well as the relative efficiency gap between sectors determines a decrease in the expected productivity gains.

There are also other conditions that may explain the low level of productivity:

The process of industrialization which may give rise to a vicious circle characterized by low innovative capacity, reduced competition, increased unemployment, 
underemployment of regional resources, all condemning the regional economy to sharp decline, especially if it proves unable to apply a rapid reconversion towards sectors that can exploit the potential.

The industrial traditionalist character which arises when conditions external to the economic structure allow relative maintenance of employment levels at the expense of productivity growth and therefore medium term development prospects.

The monopolistic barriers that prevent entry by new firms, the low mobility of resources from one sector to another, the trade protectionism, and subsidy policies are also factors that contribute to such a situation. It may be considered that this is the natural effect of the action of social groups inevitably tending to minimize the social cost of change and limit its consequences on employment.
Labor intensive growth - a situation which favors the development of local industries or can be linked to the case of peripheral areas within some regions. Given the simultaneous changes occurring in productivity and employment, there can be schematically identified regional policy types (Polese, 1994), taking into account the correlation between productivity growth and employment growth.

If $(\mathrm{Y} / \mathrm{E})$ is the productivity growth rate, $(\mathrm{E})$ is the employment growth rate, and (Y) represents the growth rate of GDP (income), there can be shown that (Y / E) + $(\mathrm{E})=(\mathrm{Y})$, and the local disparities can be assessed by comparison with an average of variables at regional level or with the ones of the micro-region which is considered as standard.

The researchers can then identify at microregion level the types of conditions which are either favorable or unfavorable to development. (Table No. 2).

Tab. No. 2- Typology of Conditions at Region Level

\begin{tabular}{|l|l|l|l|l|}
\hline & Condition type & Rate P=Y/E & Rate (Y) & Employment rate (E) \\
\hline 1 & Stable situation & Above average & Above average & Positive \\
\hline 2 & Reconversion & Above average & Above average & Above average, but negative \\
\hline 3 & Restructuring & Above average & Above average & Below average, negative \\
\hline 4 & Abandonment & Above average & Below average & Below average \\
\hline 5 & Deindustrialization & Below average & Below average & Below average \\
\hline 6 & Industrial traditionalism & Below average & Below average & Above average \\
\hline 7 & Labor intensive growth & Below average & Above average & Above average \\
\hline \multicolumn{4}{|l}{ Source: Table accomplished based on the Polese model }
\end{tabular}

Considering $\mathrm{Y}_{\mathrm{r}}=(\mathrm{Y} / \mathrm{E})_{\mathrm{r}}+(\mathrm{E})_{\mathrm{r}}=$ constant $=$ the average at region level, the microregions will be found in one of the seven areas, depending on the movement of the variables considered.

Such an analysis can be considered in the foundation of future options on the attitude on the future of local or regional administrative units.

\section{Applying the Model to the Regions of Development in Romania}

Based on this model, the researchers sought to identify the situation of the regions of development in Romania. Thus, the average growth rate were calculated for the three indicators (GDP, productivity and employment) considered in the theoretical model for each region in Romania (Table no. 3). 
Tab. Nr.3- The Growth Rate for Productivity, Employment and, Respectively, GDP for the Regions of Development in Romania

\begin{tabular}{|l|r|r|r|}
\hline $\begin{array}{c}\text { Regions of } \\
\text { development }\end{array}$ & Average rate GDP & $\begin{array}{c}\text { Average rate P } \\
\text { (GDP/E) }\end{array}$ & \multicolumn{1}{c|}{ Average rate E } \\
\hline North East & 1.078920133 & 1.077612349 & 1.00121359 \\
\hline South East & 1.092623811 & 1.087503814 & 1.00470803 \\
\hline South - Muntenia & 1.117759513 & 1.118924454 & 0.99895887 \\
\hline $\begin{array}{l}\text { South - Vest } \\
\text { Oltenia }\end{array}$ & 1.107658893 & 1.119204031 & 0.98968451 \\
\hline West & 1.125013464 & 1.120849246 & 1.00371523 \\
\hline North - West & 1.102456361 & 1.107001683 & 0.99589402 \\
\hline Centre & 1.095519775 & 1.09766366 & 0.99804687 \\
\hline Bucharest - Ilfov & 1.134847429 & 1.113656465 & 1.01902828 \\
\hline Total & 1.109195761 & 1.10792019 & 1.00115132 \\
\hline
\end{tabular}

Comparing the average rates of the three indicators in each region with the one established at national level, the following situation can be observed (Table no. 4):

Tab. No. 4- Typology of Conditions at the Level of the Regions of Development in Romania

\begin{tabular}{|l|l|l|l|l|}
\hline \multicolumn{1}{|c|}{$\begin{array}{c}\text { Region of } \\
\text { development }\end{array}$} & $\begin{array}{c}\text { Productivity } \\
\text { rate (GDP/E) }\end{array}$ & \multicolumn{1}{c|}{ Rate GDP } & \multicolumn{1}{c|}{ Rate E } & \multicolumn{1}{c|}{$\begin{array}{c}\text { Situation in } \\
\text { region }\end{array}$} \\
\hline North - East & Below average & Below average & $\begin{array}{l}\text { Above } \\
\text { average }\end{array}$ & $\begin{array}{l}\text { Industrial } \\
\text { traditionalism }\end{array}$ \\
\hline South - East & Below average & Below average & $\begin{array}{l}\text { Above } \\
\text { average }\end{array}$ & $\begin{array}{l}\text { Industrial } \\
\text { traditionalism }\end{array}$ \\
\hline South - Muntenia & Above average & Above average & $\begin{array}{l}\text { Below } \\
\text { average }\end{array}$ & Stable situation \\
Oltenia & Above average & Below average & $\begin{array}{l}\text { Below } \\
\text { average }\end{array}$ & Abandonment \\
West & Above average & Above average & $\begin{array}{l}\text { Above } \\
\text { average }\end{array}$ & Stable situation \\
North - West & Below average & Below average & $\begin{array}{l}\text { Below } \\
\text { average }\end{array}$ & $\begin{array}{l}\text { Deindustrializatio } \\
\text { n }\end{array}$ \\
\hline Centre & Below average & Below average & $\begin{array}{l}\text { Below } \\
\text { average }\end{array}$ & $\begin{array}{l}\text { Deindustrializatio } \\
\mathrm{n}\end{array}$ \\
\hline Bucharest - Ilfov & Above average & Above average & $\begin{array}{l}\text { Above } \\
\text { average }\end{array}$ & Stable situation \\
\hline
\end{tabular}

Source: table set up based on data in table no. 3

In Table 4 it can be seen that we face a situation of abandonment (South West region), which shows a difficult situation. In this region there are counties in which great emphasis was put on agriculture and mining and manufacturing, a case in which productivity is low. The active population is aging and the equipment is outdated, generating a high degree of pollution. Generally, the regions in this situation have a peripheral position in relation to a central region ("core" region), they cover fairly large areas, but their population is less numerous or dispersed. Here can be also added the isolated regions (e.g. some mountainous regions), which do not dispose of a communication network, or of proper infrastructure.

Also in these regions a range of engineering industries have been developed, industries that until two decades ago had an important contribution to the national production (including export), but which 
now have decreased. The lagging behind can be explained by the lack of resources, by conditions which are less favorable for development compared to other regions. The income per capita is low, the rates of underemployment and unemployment are high, the tax revenue sources are scarce, and labor productivity is low. Often, the population migrates first from villages to large urban centers, before leaving the region itself. The structural adjustment problems of these regions are sometimes in a strong dependence on the primary sector, which reduces flexibility in adaptation, while their main production is characterized by poor elasticity in relation to revenues.

The people with high availability towards migration are usually youth, belonging to the working population, who migrate to urban areas in search of better jobs and a more attractive social life. It is usually about the young people aged between 20 and 39 years old. It should be noted that there also is a phenomenon of migration towards rural areas, more specifically for the population aged 40 and over, and it affects the entire country. Generally, it is mostly the case of people who, subsequent to the restructuring of state companies, have failed to be readjusted and so were forced to return to rural areas where they undergo subsistence activities. The lack of adequate jobs has led to massive migration of the population as unskilled labor abroad.

In exchange for these declining industries, the region could not take advantage of other available resources that could be used rationally by developing other industries or sectors such as tourism, which could have been developed due to the Danube. But this requires proper management (consistent government policies of support, and also financial possibilities). All these have a significant negative impact on the welfare of the population in the region.

There are two regions which face deindustrialization. These include the counties in Transylvania. Large enterprises on ore exploitation and processing were developed in this area over the past, which have currently significantly reduced their activity (e.g., the factories in Baia Mare, Zlatna, Copsa Mica, Zalau, etc.). This led to rising unemployment, therefore to the underemployment of available regional resources, which further led to decreased competitive capacity, however due to the reduced innovative capacity of companies. Therefore, it can be observed that all three indicators are below the national average, including the case of employment. This is due to increased emigration, basically aiming at family reunification, then due to ethnic belonging (the fleeing of Saxons and Hungarians), to seeking better paid employment (in Italy, Spain, Germany, the UK etc..) and last but not least to the exodus of young people of higher qualification. This situation could be improved through controlled national or international immigration. However, these regions have managed to maintain a higher level than the South-West Oltenia region due to external links that have been maintained (because of the proximity to western markets). The causes may be found in the effect of "positioning" (some sectors tend to deteriorate more in some regions than in others, this resulting in an overall deficit) and in the "structural" effect (the enterprises within a region focus their activity in sectors which are considered to "lose speed" in relation to the results recorded nationally).

The economic situation of the counties in the east of the country (the South-East and North-East regions) is characterized by industrial traditionalism. Analyzing the situation of the three indicators taken into account, it can be observed that only for the employment index its average value is higher than the national average, which shows a less favorable future situation, since it doesn't prove the regions' real possibility of intensive development, but rather of the extensive one. Regarding the South-East region, it is observed that, besides a low contribution of some areas these indicators have little influence (The Danube Delta), there are areas that have a more significant contribution and compensate, through results, the poorer contributions of other areas. These areas that generate substantial contribution are 
the waterfront territories (Constanta, Galati, Braila, etc.), but still these areas are not able to generate technical progress so as to develop innovative activities with significant social and economic effects.

The other three regions (Bucharest-Ilfov, South-Muntenia and West) are characterized, as expected, by a stable situation. These regions, due to their political and administrative geography, have managed to attract most foreign investment flows. The region Bucharest Ilfov disposes of this advantage because of the political and administrative role of the capital which attracted productive resources.

Also, the South-Muntenia Region has a favorable position in the national context, due to the proximity of the Bucharest-Ilfov Region, but also due to other available resources (e.g., the population density Prahova County registers the largest value in the country) and due to a developed infrastructure.

Region West, due to its geographical positioning has always had close contact with foreign countries. Although it has a heterogeneous structure, it consists of both economically developed areas, considered to be real growth poles (around Timisoara and Arad), and also of mono-industrial areas (Petrosani, Anina) with a negative contribution to the regional and national production and serious social problems. The county of Caras-Severin is further mentioned, which adds other economic and social problems. However, a favorable situation can be noted at regional level, which translates into an important contribution of the developed areas to and their favorable position in - the national and international economy, having thus the ability to offset the negative effects induced by the less developed areas. This region - just like the other regions in Transylvania - benefits of external links that have been maintained and developed by emigrants who had left these counties. In addition, this region is geographically much closer to Western European countries.

\section{Conclusions}

To conclude, these regions with a stable situation can be considered to be emerging regions, with very close relationships abroad (these relationships are also to be found in other regions, within the Carpathians). Thus, disruptions in the global economy are more easily transmitted on these regions. This way, facing the crisis, the economic and social impact - which is likely to be felt - will be more difficult to bear compared to the situation of other regions which are not as well connected to the global economic system. But the counties that registered until recently the lowest GDP / capita will do better facing the effects of the crisis, including the regions in the South, SouthWest and the Eastern part of the country. Basically, these counties are mainly agricultural, predominantly rural and are still tributary to traditional economic relations.

Regional disparities remain between development regions in Romania, although regions with lower income benefit from a higher percentage of the structural funds.

For Romania, as in the case of other new EU member countries, there is a clear structure of center - periphery type, a structure which is self-sustained by a faster growth of the regions around the capital, due to investments that prefer developed areas, labor migration and government intervention in the more developed regions to achieve a higher growth rate at national level.

\section{Acknowledgement}

This paper benefited from financial support through the project „Postdoctoral Studies in Economy: continuous training program of elite researchers - SPODE" co-financed by The Social European Fund, through The Operational - Sectorial Human Resources Program 2007-2013, contract no. POSDRU/89/1.5/S/61755.s 


\section{References}

Alexandrina, D. (2003). 'Macroeconomie Aprofundată,' (Advanced Macroeconomics), Mirton Publishing House, Timişoara.

Antonescu, Daniela (2003). 'Dezvoltarea Regională În România: Concept, Mecanisme, Instituţii,' (The Regional Development in Romania. Concept, Mechanisms, Institutions), Oscar Print Publishing House, Bucharest.

Anuarul Statistic al României (The Yearly Statistical Book of Romania) 2005 -2010.

Armstrong, H. W. \& Taylor J. (2000). Regional Economics and Policy, Blackwell.

Bal Ana, Luţaş Mihaela, Jora, O. \& Topan, V. (2007). Scenarii Privind Evoluţiile Comunitare În Domeniul Competitivităţii, Politicii De Coeziune Şi Politicii De Dezvoltare Regională, (Scenarios on Communitarian Development in the Fields of Competitiveness, Cohesion Policy and Regional Development Policy) Institutul European Din România - Studii De Strategie SSi Politici (The European Institute In Romania - Studies on Strategy and Policies), SPOS 2007, Bucharest.

Constantin, Daniela-Luminița (2001/2002). 'Economie Regională- Sinteze,' (Regional Economics. Synthesis), Oscar Print Publishing House, Bucharest, 1st Ed. - 2001, 2nd Ed., Revised In 2002.

Constantin, Daniela-Luminiţa (2004). 'Elemente Fundamentale De Economie Regionala,' (Basic Issues of Regional Economics), The Publishing House of the Academy of Economic Studies, Bucharest.

De Ce 0 Politică Regională? (Why a Regional Policy), www.eufinantare.info, (accessed on 21.01.2009).

Dobrescu, E. (1996). 'Integrare Economic,' (Economic Integration), The Publishing House of the Romanian Academy, Bucharest.
Dornbusch R., Fischer S. \& Startz R. (2007). 'Macroeconomie (Macroeconomics),' Editura Economică, Bucharest.

Fingleton, B. (2003). European Regional Growth, Editura Springer, New York.

François Eymard-Duvernay (1981). Les Secteures De L'industrie Et Leurs Ouvriers, Economie Et Statistique, No. 138.

Frentz, G. (2003). 'Aspecte Ale Politicii De Dezvoltare Regională În România,' (Aspects of the Regional Development Policy in Romania), In C. Pârlog, D.L. Constantin (Eds.), Dezvoltare Regională Şi Integrare Europeană (Regional Development and Economic Integration, Proceedings of the 2nd Natioinal Symposium of the Romanian Association of Regional Sciences, Oscar Print Publishing House, București.

Hoover, E. M. \& Giarratani, F. (1989). An Introduction to Regional Economics, Macmillan, New York.

Ionescu, C. \& Toderaş N. (2007). 'Politica De Dezvoltare Regională,' (The Regional Development Policy), Tritonic Press, București.

Iuhas, V. (2004). 'Dezvoltare Economică Regională - Implicaţii Economice Şi Sociale,' (Regional Economic Development - Economic and Social Implications), Emia Publishing House, Deva, Romania.

Jivan, A. \& Paţac, F. (2004). Istoria Economică a României (The Economic History of Romania) Mirton Publishing House, Timişoara, Romania.

Jula, D. (2002). 'Economia Regionala,' (Regional Economics), Estafalia Publishing House, Bucharest, Romania.

Jula, D., Ailenei, D., Jula, N. \& Gârboveanu, A. (1999). 'Economia Dezvoltării,' Teoria Dezvoltării- Probleme NaţionaleDimensiuni Regionale (Development Economics. Development Theory - National Issues - Regional Dimensions), Viitorul Românesc Publishing House, București. 
Jula, D. \& Valentin, N. (1997). Previziuni Privind Dezvoltarea Regională În Condiţiile Economiei De Piaţă (Forecasting on Regional Development in the Conditions of the Market Economy), The Publishing House of the Academy of Economic Studies, Bucharest.

Krugman, P. R. \& Venables, A. J. (1991). 'The Spatial Economy,' Cities, Regions and International Trade, Cambreige (MA), Mit Press, Massachusset.

Legea nr. 151/1998 Privind Dezvoltarea Regională În România (Law151/1998 on Regional Development in Romania), www.adrvest.ro.

Legea nr.315 /2004 Privind Dezvoltarea Regionala În România (Law 315/2004 on Regional Development in Romania) (MO nr. 577 / 29.06.2004),www.adrvest.ro.

Manolescu, G. \& Istudor, N. (2007). Logistica Proiectării Dezvoltării RegionaleAnaliză, Strategie, Programare, Finanţare, Management (The Logistics of the Regional Development Design - Analysis, Programming, Financing, Management), The Publishing House of the Academy of Economic Studies, Bucharest.

Miron, D. (2000). 'Integrarea Economică Regională: De La Prototip La Producţia În Serie,' (Regional Economic Integration: From Prototype to Series Production), Sylvi Publishing House, București.

Moşteanu, N. R. (2003). 'Finanţarea Dezvoltării Regionale În România,' (Financing Regional Development in Romania), Economic Press, Bucharest, Romania.

Mureșan, Maria (Ed.) (2008). 'Procesul De Integrare a României În Economia Europeană,' Dimensiuni Istorice Și Contemporane (Romania's Integration in the European Economy. Historical and Contemporary Dimensions), The Publishing House of the Academy of Economic Studies, Bucharest; București.

Murgescu, B. (2010). 'România Și Europa. Acumularea Decalajelor Economice (1500 -
2010),' (Romania and Europe. Accumulation of Economic Disparities) Polirom Publishing House, Iași, Romania.

Mutaşcu, I. (Ed), Crâsneac, A., Danuleţiu, D., Dogaru, E. \& Enache, E. (2008). 'Modele De Finanţare a Dezvoltării Regionale,' (Models of Regional Development Funding), Mirton Publishing House, Timişoara, Romania.

Părean, M. (2009). 'Preţul Creșterii Economice Româneşti,' (The Price of Romanian Economic Growth), West University Press, Timişoara.

Pascal Ileana, Vlad Monica, Deaconu, S. \& Vrabie C. (2004). 'Politica Regională Şi Coordonarea Elementelor Structural,' (Regional Policy and Coordination of Structural Items), Bucharest.

Planul Naţional de Dezvoltare 2004-2006 (The National Plan for Development 20042006) www.adrvest.ro.

Planul de Dezvoltare Regională 2007 2013 (The National Plan for Development 2007-2013), Agenţia Pentru Dezvoltare Regională Vest (West Agency for Regional Develooment), www.adrvest.ro.

Planul Naţional de Dezvoltare 2007-2013 (The National Plan for Development 20072013), noiembrie 2005, www.inforegio.ro.

Polese, Mario (1994). Economie Urbaine Et Regional: Logique Spatiale Des Mutations Economique, Economic Press, Paris.

Politica de Dezvoltare Regională, Seria Micromonografii- Politici Europene (Regional Development Policy, the Series of Micro-Monographies - European Policies, 2003. Programul Operaţional Regional 2007 - 2013 (The Regional Operational Program 2007-2013), www.inforegio.ro.

Raport Anual de Implementare 2007, Programul Operaţional Regional 2007 2013 (Yearly report of implementation 2007, The Regional Operational Program 2007-2013), Bucharest, 2008; www.inforegio.ro. 
Schultze, H. (2002). Stat Si Natiune În Istoria Europei (State and Nation In Europe's History), Polirom Publishing House, Iaşi.

Silaşi, Grigore (2004). 'Teoria Şi Mecanismele Integrării,' Integrarea Ţărilor Din Europa Centrală Şi De Est. Cazul României (Integration Theory and Mechanisms. Integration of Countries in Central and Eastern Europe. Romania's Case), The Publishing House of the West University of Timisoara, Romania.

Wieviorka, M. (1994). 'Spaţiul României,' (The Territory of Romania), Humanitas Publishing House, Timişoara.

\footnotetext{
1 Analysis based on the theory of Mario Polese, Economie urbaine et regional. Logique spatiale des mutations economique, Economic Press, Paris, 1994
} 